DOI https://doi.org/10.31212/zradova.17.rusijaisrbija.bje.11-13

Др Миле БЈЕЛАЈАЦ

Институт за новију историју Србије

mile.bjelajac@gmail.com

Миле БЕЛАЯЦ

Институт новейшей истории Сербии

\title{
Уводни говор директора Института за новију историју Србије
}

Поштоване колегинице и колеге, драги гости, окупили смо се 19-20. априла 2019. на Међународној научној конференцији „Русија и Србија на прелому векова. Српске теме Андреја Шемјакина”, да кроз научни дијалог осветлимо дело и рад нашег рано преминулог колеге др Андреја Леонидовича Шемјакина, научног саветника у Институту за словенске студије, Руске академије наука. Сада у сарадњи са српским и руским научним институцијама објављујемо зборник радова учесника ове конференције.

Преминуо је, после дуге и тешке болести, у родној Тули 8. марта 2018. године. Мада су његови ближи сарадници наслућивали могући крај, нисмо веровали да је то тако близу. Знали смо да је боловао, али и да се опорављао. Када сам последњи пут био у Москви седео сам у његовој некадашњој канцеларији у Институту за словенске студије. Ту је био и његов урамљени портрет. Његове ствари, књиге које су сарадници сачували као успомену на њега. Оживљавали смо га кроз разговоре, сећања, али празнина је била ту. Каква разлика у односу на 2015. годину, када смо се непрекидно дружили на скуповима и на Међународном сајму књига, где је био драг говорник, представљајући наше књиге ${ }^{1}$. Штавише, његов штампани предговор у књизи заувек ће остати као спомен нашег међусобног поштовања и пријатељства².

1 М.Белаяц, Кому нужна ревизия истории? Старые и новые споры о причинах Первой Мировой войны, Москва: Алгоритм, 2015.

2 На српском језику предговор А.Шемјакина објављен је у 3. допуњеном издању. Бјелајац М. 1914-2014 : зашто ревизија?: мењање оцена о узроцима Првог води ревизији оцена о узроцима Другог светског рата, Нови Сад-Београд, 2019. 
У Андреју Шемјакину, првом руском историчару, кога сам ближе познавао и упознао, видео сам оне „праве Русе”, како смо их некад замишљали, праве руске људе - широке душе и доброг срца. Не, оне Русе из совјетских времена, који су деловали суздржано, понекад бирократског држања, уско профилисани, помало неприступачни, но била су то таква политичка времена. Упркос фразама и лепом понашању, увек се са њима, у том периоду, осећала велика разлика у тумачењу заједничке прошлости. Овај субјективни доживљај са наших почетака, променио је управо Андреј Шемјакин. Као да смо се знали годинама, а тек смо се били срели. Отворено и без сујете примао је повремене сугестије и неке чињеничне корекције. Био је одомаћен у нашој средини. Најчешће сам га затицао у просторијама Института за савремену историју, зато што су просторије нашег Института тада биле на другој страни града. Затим, на Филозофском факултету, посебно код колеге Мирослава Јовановића. Увек је било пуно приче, али и традиционалног наздрављања, јер је то био начин опуштања у тешким временима, која су оба народа проживљавала у минулим деценијама.

Читали смо Андреја Шемјакина и отварали му странице наших Токова историје ${ }^{3}$. Радује ме данас што је било тако. Сада, када га физички више нема, то су парчићи његовог духа, трајно међу нама и трајаће после свих нас. Сведочиће о нашој сарадњи и још једном, заиста, дубоком пријатељству. Не могу да заборавим колико су он и још неки пријатељи покојног професора Мирослава Јовановића показали привржености, не часећи ни часа и дошли су у Београд на

3 За две деценије у «Токовима историје» објављено је десетак радова А.Шемјакина: Нова писма Николе Пашића митрополиту Михаилу (1884- 1885). // Токови историје. 1-2, 1995, 233-259; Никола Пашич и русские социалисты в Цюрихе (1868-1872 гг.) // Токови историје. 1-2, 1997, 5-40; Идеология Николы Пашича. Формирование и эволюция. // Токови историје. 1-4, 1999, 271-311; Сербия на переломе. Обретение независимости и проблема модернизации. // Токови историје. 1-2, 2000, 19-46; Никола Пашић у успоменама руског путника (прилог проучавању идејног порекла Српске народне радикалне странке). // Токови историје. 3-4, 2003, 99-109; Генерал М. Г. Черняев и сербская война // Токови историје. 1-2, 2006, 7-28; Как убивали в Белграде Георгиевского Кавалера. // Токови историје. 3, 2007, 7-16; Историчар Владимир Константинович Волков (у сарадњи са К.В.Никифоровим) // Токови историје. 1-2, 2009, 177 192; Генерал «от коммерции». М.Г. Черняев в Сербии в 1879-1881 гг. // Токови историје. 3, 2012, 361-378; Сербия и Сербы накануне Балканских войн глазами русских (к дискуссии о «современном» государстве). // Токови историје. 1, 2015, 37-43. 
његову сахрану. То ме је дубоко дирнуло и само је потврдило колико смо били узајамно повезани, не само као историчари, већ и као другови. Овим научним скупом и зборником ћемо му се макар мало одужити и још једном подсетити на његово научно дело, на његов допринос у изучавању српске прошлости и српско-руских веза и на трајне вредности у том делу.

Шемјакин је суочио више врста извора и две историографије - српску и руску. Тиме је ушао у полемику са не малим бројем митова који су у историјски наратив ушли директно из политике. Томови грађе о животу човека на Балкану, односима Русије и Србије током Првог светског рата и друго, само потврђују да је он био, не само истакнути истраживач какав је иначе био, већ и организатор науке, ментор, руководилац у једном читавом пољу „српских студија“ у Русији. Његовим одласком највише су изгубили његови најближи пријатељи, изгубила је руска наука о Балкану, изгубио је његов Институт за словенске студије, али изгубили смо и ми, његове колеге и пријатељи из Србије.

Нека му је вечни помен и слава! 